\title{
Thematization in Native and Nonnative Medical Discourse: A Systemic- Functional Approach
}

\author{
Mashael Alrajhi \\ Princess Nourah bint Abdulrahman University, Kingdom of Saudi Arabia \\ maalrajhi@pnu.edu.sa
}

DOI: $\underline{\text { http://doi.org/10.36892/ijlls.v2i2.270 }}$

\begin{tabular}{|c|c|}
\hline $\begin{array}{l}\text { Received: } \\
\text { 25/04/2020 }\end{array}$ & $\begin{array}{l}\text { Abstract } \\
\text { Thematization serves to focus the readers' attention to the focal aspects of a }\end{array}$ \\
\hline $\begin{array}{l}\text { Accepted: } \\
\text { 18/05/2020 }\end{array}$ & $\begin{array}{l}\text { text in order to deliver its intended interpretation. The cohesion of texts relies } \\
\text { on the structure of messages. Consequently, the way in which messages are } \\
\text { constructed as the text unfolds contributes to its cohesion. Since the probability } \\
\text { of making mistakes in writing is higher in nonnative texts as their writers are }\end{array}$ \\
\hline $\begin{array}{l}\text { Keywords: } \\
\text { Medical Discourse; } \\
\text { Systemic Functional } \\
\text { Linguistics (SFL); } \\
\text { Textual Metafunction; } \\
\text { Thematic Progression; } \\
\text { Theme Analysis }\end{array}$ & $\begin{array}{l}\text { not using their mother tongue, a comparison between medical articles written } \\
\text { by native and nonnative writers is drawn in the present study to shed light on } \\
\text { the similarities and differences among them. Due to the scientific nature of } \\
\text { medical texts, writers might face difficulties in the interconnectedness of ideas } \\
\text { within the text. Therefore, the medical field texts are inspected to check their } \\
\text { correspondence with texts in other fields. The Hallidayan systemic-functional } \\
\text { approach (SFL) was utilized to conduct the analysis. The results show that there } \\
\text { is a consistency in the distribution of Theme types and Thematic progression } \\
\text { patterns among native and nonnative writers. In addition, the findings that } \\
\text { relate to the dominance of the topical Theme and the constant Theme pattern in } \\
\text { medical texts are in alignment with the results of studies in other fields such as } \\
\text { academia. }\end{array}$ \\
\hline
\end{tabular}

1.INTRODUCTION

The architecture of language is based on the production of text. In linguistics, the term text refers to "any passage, spoken or written, of whatever length, that does form a unified whole" (Halliday \& Hasan, 1976, p.1). As Halliday and Hasan (1976) argued, texts are best regarded as semantic units not of form but of meaning. Therefore, the delivery of meaningful messages in texts is of a paramount importance. Systemic Functional Linguistics (SFL), founded by the works of Halliday, is a "very useful descriptive and interpretive framework for viewing language as a strategic, meaning-making resource" (Eggins, 2004, p. 2). Halliday's Systemic Functional approach to language shows how ideational, interpersonal, and textual meanings, or metafunctions as Halliday calls them, are expressed in clause structures. The principal systems of the clause are theme, mood, and transitivity (Halliday \& Matthiessen, 2004). Of the three metafunctions, the current study relates to the textual metafunction which studies the Theme and information structure of texts.

As the text unfolds, the way in which messages are constructed contributes to its cohesion. Therefore, it is quite apparent that there is a close semantic relationship between information structure and thematic structure. Halliday defines Theme as "the point of departure" for the message, and so it falls within what is called Given information (Halliday \& Matthiessen, 2004, p. 93). This means that speakers usually start their messages with information that has already been mentioned in the text, or that is shared or believed to be of mutual knowledge among the participants of the interaction. In the sentence Sarah bought a new car, for example, the Theme is Sarah. The rest of the sentence basically forms what is known as the Rheme, which typically contains information that is unfamiliar or New. Halliday 
categorizes the Theme into three types: topical, interpersonal, and textual (Halliday \& Matthiessen, 2004). It is possible to have more than one type of Theme in a clause, which is referred to as Multiple Themes. However, of these three types, the topical Theme is obligatory, whereas the other types are optional. A topical Theme is usually an element that occurs at the beginning of a clause, and to which a transitivity role can be assigned such as a participant, circumstance, or process (Eggins, 2004). An interpersonal Theme is a constituent to which a Mood label is assigned. These constituents are interrogatives and the four categories of Modal Adjuncts, which are Mood, Vocative, Polarity, and Comment (Eggins, 2004). A textual Theme is the constituent that relates the clause to its context. The two main types of textual Themes are Continuity Adjuncts and Conjunctive Adjuncts (Eggins, 2004).

Thematic progression was introduced by Daneš (1974) to refer to what he describes as "the skeleton of the plot" (p.114). It refers to information flow patterns in a text and the way in which information is exchanged between the pairings of the Theme and Rheme (Halliday \& Matthiessen, 2004). There are three main patterns for thematic development: Theme reiteration (constant Theme), the zig-zag pattern (linear Theme), and the multiple Theme pattern (split Rheme) (Eggins, 2004). Theme reiteration basically means that the same element occurs regularly as Theme (Eggins, 2004). For example, in the sentences Nawwaf is a doctor. He works at King Khalid hospital, the use of He refers to the same Theme. In the zig-zag pattern, the element that is introduced as a Rheme in the first clause becomes the theme of the following clause (Eggins, 2004). An example of this pattern can be observed in the sentences Monica handed her son an ice-cream cone. It fell off his hands and caused a mess. It, which is the Theme of the second clause, refers to the ice-cream cone which is the Rheme of the first clause. The third pattern is the multiple Theme pattern. In this pattern, the Theme of one clause introduces a number of different pieces of information in the Rheme, each of which is taken up and made Theme in the following clauses (Eggins, 2004). For example, in a paragraph that starts with a sentence like The three stages of making a cake are mixing ingredients, oven baking, and decorating, the three elements of the Rheme can be split into Themes in the following clauses.

As texts are carriers of meaning, the way we combine Given and New types of information plays a very important role in highlighting the focus of our interactions. In a clause, whatever is chosen to be in initial position will influence readers' interpretation of what follows. Therefore, Given information needs to be presented in the position of Theme to develop a well-constructed message. Failure of appropriately handling the flow of information and how the meaning of a text unfolds leads to the production of an incoherent, unintelligible text.

The systemic functional approach, as Halliday explains, is "comprehensive" because it is concerned with language in its entirety (Halliday \& Matthiessen, 2004, p. 19). The SFL approach should be adopted because languages are not designed but rather evolved systems that cannot be explained simply as the sum of their parts like the traditional compositional way of approaching grammar (Halliday \& Matthiessen, 2004).

Language teachers often address students' writing problems that are below the clause level, such as incorrect uses of verb tenses, or the lack of subject-verb agreement (Wang, 2007). However, observing discourse level problems, such as Thematic progression and patterns of Theme and Rheme relations, helps writers maintain cohesion in their writings. Several studies were conducted on the description of medical writing (Salager-Meyer 1994; Gotti \& SalagerMeyer, 2006; Atkinson \& Valle, 2012), but only a few studies used SFL as an approach to study medical writings (Rodríguez-Vergara, 2017). The nature of text in medical articles largely differs from that of other types of writing in the sense that, as a scientific text, it is expected to be difficult (Halliday \& Webster, 2004, p. 159). Readers of texts in scientific disciplines might encounter difficulty because such texts sometimes appear obscure. This problem might be attributed to the "scientific language" in which they are written (Halliday \& Webster, 2004, p. 159). While the difficulty of the terminology used in scientific discourse is 
always perceived as the cause of texts' obscurity, Halliday believes that if we want to understand the difficulty of scientific texts, we "need to get rid of our obsession with words", because the difficulty "lies more with the grammar than with the vocabulary" (Halliday \& Webster, 2004, p. 161). Both, the words and the structure, are part of this difficulty. Halliday claims that "not only ESL students who find problems with scientific English — so also do many for whom English is the mother tongue" (Halliday \& Webster, 2004, p. 159). While the two groups, as Halliday explains, may respond to scientific English in different ways, the difficulties they face have the same features.

Based on Halliday's SFL textual metafunction, this study aims to explore Theme analysis and the Thematic progression of medical articles published by native and nonnative writers of English. Publications of medical sciences carry a lot of weight not only in the realm of academia but also as a remarkable source of knowledge in the healthcare context and our daily life. The largest number of international publications, according to an analysis of Saudi output by field of study, belongs to the medical sciences (Al-Ohali \& Shin, 2013). Because medical articles that are published by nonnatives are naturally not written in their mother tongue, the current study investigates whether there are differences between medical articles written by native and nonnative writers in relation to their use of Theme and Rheme, as well as the Thematic progression of their articles. In addition, the study will inspect whether the findings of Thematic progression and Theme types analysis of medical texts corresponds to those of other fields.

\section{LITERATURE REVIEW}

Many SFL text-based studies have been conducted to investigate Theme and information structure, and examine Thematic progression patterns. Such studies scrutinize students' writings or productions that relate to a specific workplace context to shed light on the textual features of those texts and provide an opportunity for improvement.

Abdul Ridha (2014) conducted a study on the frequency and functional analysis of thematization in essay writings of EFL students in the English department at Basra University. Based on SFL's theory, she addressed the relationship between Themes and Rhemes in students' sentences, and discussed some problems that relate to Theme and Thematic progression which were found in students' texts. The findings indicated that unmarked Themes were the dominant type that was used in students' essays. Of topical Theme types, nominal group Themes recorded the highest percentage. The results also confirmed the existence of some Theme problems in students' writings such as the problem of the brand new Theme, the over-use of the word there as a Theme, empty Rheme and non-constant progression, and Themes that have unclear reference.

Gunawan \& Aziza (2017) conducted a study to analyze the choice of Theme and Thematic progression in theses written by undergraduate students in Indonesia. They adopted a Hallidayan approach to conduct the analysis. The results showed that students followed the conventional features of good academic writing which involved the use of all three types of Theme: topical, interpersonal, and textual. The topical Theme was the dominant type in students' writings. In relation to Thematic progression, the dominant type was Theme reiteration, followed by the zig-zag pattern and then the multiple Theme pattern. The study's findings were consistent with academic text disciplines and the use of cohesion. The study provided a detailed investigation and a thorough analysis of undergraduate students' writings.

A study by Noori (2015) adopted a Hallidayan approach to provide a detailed analysis of textual Themes in M.A. theses and Ph.D. dissertations that were written by Iraqi EFL learners. The paper aimed to investigate the similarities and differences between them in relation to the use of textual Themes. The results showed that though M.A. theses and Ph.D. dissertations obviously differed in terms of scientific and academic levels, their use of textual Themes was similar. The findings also provided evidence of a higher tendency to use conjunctive adjuncts and conjunctions than the use of relatives. This is attributed to the fact that conjunctive adjuncts 
and conjunctions express logical links between the parts of a text, which helps readers understand it. In relation to Halliday's classification of conjunctive adjuncts and conjunctions according to their meanings, the results showed a semantic similarity between M.A. theses and $\mathrm{Ph} . \mathrm{D}$. dissertations in using enhancement more than the other semantic types.

Alyousef (2015) adopted a systemic functional multimodal discourse analysis approach to conduct an investigation of Theme and information value in students' writings. The texts examined were finance assignments written by postgraduate business students. The results indicated that with regard to Theme patterns, students used a high frequency of Theme reiteration, followed by a low use of linear Themes while multiple Themes represented a minimal number. While many studies have been conducted on EFL students', this study's significance stems from its focus on the manner in which international business students construct cohesive, multimodal finance texts.

An SFL study by Wang (2007) tackled the relationship between Themes and Rhemes with the aim of improving cohesion in academic texts. The researcher diagnosed a text written by a student who is a sophomore majoring in Politics from South-Eastern University in China. The findings showed that the student's writing had problems with Thematic progression. The text was lacking in the development of ideas due to the lack of cross-referential Thematic progression that works as a link to provide a more dynamic effect. Another problem that was diagnosed in the text was the overuse of constant progression, where the same Theme is chosen over several clauses or sentences. In addition, the problem of Theme and Rheme misuse was found in the student's writing. The researcher provided a theoretical overview and demonstrated the application of SFL on the student's writing with possible solutions.

Patpong (2013) examined the Thematic progression patterns of Thai Song Dam folktales. The data were composed of ten Thai Song Dam folktales. The author followed Daneš' categorization of Thematic progression types. The findings showed that the most frequently used pattern of Thematic progression was the constant Theme pattern. Both ellipsed and nonellipsed topical Themes were used as constant Themes. The linear Theme pattern was ranked second. The least frequent Theme pattern was the split Rheme.

In relation to the medical field, a study based on the SFL approach by Rodríguez-Vergara (2017) tackled the passive voice in a medical research article that was translated from English into Spanish. Theme and Rheme analysis was conducted to both the original and the translated articles, and all the instances of the active and passive voices in the texts were compared. The findings indicated that the use of the reflexive passive in Spanish led to a change in the original Thematic patterns of the text in English.

A comparative study on medical texts was conducted by Kazemi (2015) to compare similarities and differences of Theme markedness in Persian and English. The corpus of texts for analysis comprised data from the two languages, containing samples of academic texts taken from two books in the field of medical science as well as four medical articles. The results of the analysis show that some Persian properties, specifically being pro-drop and having nonfixed word order, distinguished it from English with regard to markedness. Many circumstantial adjuncts in the subject position of Persian medical texts sound unmarked to Persian native speakers. In addition, some factors that relate to Theme markedness, such as specific genres, writers' style differences, and writing types, are regarded as similarities between the two languages, whereas the differences pertain to the structures of Persian and English.

The analysis of thematic structure and progression of texts helps with the improvement of textual cohesion in academic and scientific texts. Although many studies tackle the analysis of Theme in the writings of EFL undergraduate students whose major is English, there is a lack of text-based analyses in the medical field. The present study aims to explore the similarities and differences of Theme analysis and Thematic progression in medical articles written by native and nonnative writers. 


\section{METHODOLOGY}

The corpus of the study consisted of seven recent medical articles (20,904 words) written in English and published between 2015 and 2019. They are all related to one medical topic: Intravenous Fluids (IV). The articles are written by native and nonnative writers of English. The native articles were written by authors from the UK, the USA, and Northern Ireland, and the corpus was comprised of four articles (10,756 words) - article 1 (2142 words), article 2 (3055 words), article 3 (2854 words) and article 4 (2705 words). The nonnative articles were written by authors from Saudi Arabia, Egypt, and Iran, and the corpus was comprised of three articles (10,148 words) - article 1 (3825 words), article 2 (2303 words), and article 3 (4020 words). The data were composed of complete article texts excluding the abstracts, cover pages, references, tables and figures. Although the articles are written by writers from different countries and have slight differences in their formatting, they are comparable because all of them revolve around the same medical topic, which is Intravenous Fluids (IV).

Using Halliday's analytical tool of Theme analysis and Thematic progression, the study seeks to explore the ways in which writers of medical articles compose coherent medical texts and tries to identify possible problems in their writing. SFL is a suitable tool to be applied to the current study because analyzing the Theme and Rheme and inspecting Thematic progression shows how medical discourse writers organize their articles, and sheds light on problems that can hinder the delivery of clear meanings due to a lack of cohesion.

The analysis of the corpus went through several steps. Firstly, the articles were analyzed into clauses, showing the Themes and Rhemes in tables, as well as the three types of Theme: topical, textual, and interpersonal. Secondly, the Thematic progression patterns in native and nonnative texts were identified. Thirdly, statistical information in relation to Theme frequencies were calculated (see Appendix A and B). Finally, the frequencies of the Thematic progression patterns found in native and nonnative texts were also calculated (see Appendix $\mathrm{C}$ and $\mathrm{D}$ ). In order to make the study reliable, and avoid the effect of any differences in length, the use of percentages based on calculations of occurrences was employed to reflect the extent to which the two types of texts are similar or different in relation to the placement of various textual elements. Moreover, this approach could provide a better view of the disparity between the rhetorical devices used by the authors of the analyzed scientific texts.

\section{RESULTS AND DISCUSSION}

The current study focused on the clause as a unit of investigation. Following the Hallidayan tradition, and by analyzing the thematic structures of a text clause by clause, "we can gain an insight into its texture and understand how the writer made clear to us the nature of his underlying concerns" (Halliday \& Matthiessen, 2004, p. 105). Although the corpus of native and nonnative texts was comprised of an approximately similar count of words (around 10,000 words each), there was an evident difference in the number of clauses. The total number of clauses in the corpus of native texts was 814, whereas it was a total of 536 in nonnative texts. The apparent variation in the number of clauses can be attributed to the very long sentences produced by nonnative writers of English. The following parts contain analyses of Theme types and Thematic progression, followed by a description of some problems of thematic selection and progression.

\section{Analysis of Theme Types}

The analysis of the frequencies of Theme types in native and nonnative texts revealed the dominance of topical Theme over the other types in both texts. Interestingly, the findings showed that the distribution of different types of Themes in each text was similar. Topical Themes (including ellipsed Themes) comprised $68.12 \%$ and $67.29 \%$ of the total occurrences of Themes in native and nonnative texts respectively. The most dominant type of topical Themes in all the analyzed texts is nominal groups. Other topical Theme types include 
referential items and rare occurrences of personal pronouns, mainly to refer to authors of previous studies. Table (1) shows the distribution of Theme types in native and nonnative texts.

Table 1. Theme Types in Native and Nonnative Texts

\begin{tabular}{llclcccc}
\hline Text type & Occurrences & $\begin{array}{l}\text { Topical } \\
\text { Theme }\end{array}$ & $\begin{array}{l}\text { Ellipsed } \\
\text { topical } \\
\text { Theme }\end{array}$ & $\begin{array}{l}\text { Textual } \\
\text { Theme }\end{array}$ & $\begin{array}{l}\text { Interpersonal } \\
\text { Theme }\end{array}$ & $\begin{array}{l}\text { Total } \\
\text { number of } \\
\text { Themes }\end{array}$ \\
\hline $\begin{array}{l}\text { Nonnative } \\
\text { texts }\end{array}$ & $\begin{array}{l}\text { Frequency } \\
\text { Percentage }\end{array}$ & 479 & $60.25 \%$ & $7.04 \%$ & $32.20 \%$ & $0.50 \%$ & $100 \%$ \\
\hline $\begin{array}{l}\text { Native } \\
\text { texts }\end{array}$ & Frequency & 663 & 151 & 361 & 20 & 1195 \\
\hline
\end{tabular}

As shown in table (1), the occurrence of textual Themes was ranked second among Theme types in both texts. Textual Themes occurred with a percentage of $30.21 \%$ in native texts and $32.20 \%$ in nonnative texts. Because of the nature of scientific texts, the use of interpersonal Themes scored the lowest percentage among the other types of Theme in both texts. In native texts, interpersonal Themes comprised $1.67 \%$ of the total number of Themes, and a low percentage of only $0.50 \%$ was found in nonnative texts. This is attributed to the objectivity and impersonal traits that scientific texts are known for (Halliday \& Webster, 2004). In relation to the frequency of Theme types, the findings of the present study are in accordance with previous studies on Theme analysis in academic texts such as those by Abdul Ridha (2014) and Gunawan and Aziza (2017). Topical Themes are the dominant type, followed by textual Themes, and as expected, the least occurrences were those of interpersonal Themes.

\section{Analysis of Thematic Progression Patterns}

The analysis of the patterns of Thematic progression found in native and nonnative texts revealed that all the three types existed in their writings in different distributions. However, in both text types, the most dominant Theme pattern was the constant type, followed by the linear pattern, and lastly the split Rheme pattern. Tables (2) and (3) provide examples of the three Theme patterns in native and nonnative texts respectively. 
Table 2. Thematic Progression Pattern Examples in Native Texts

\begin{tabular}{|c|c|c|c|c|c|c|c|c|}
\hline \multicolumn{9}{|c|}{ Native Texts } \\
\hline \multirow{8}{*}{$\begin{array}{l}\text { Example } \\
\text { of } \\
\text { Constant } \\
\text { Theme } \\
\text { Pattern }\end{array}$} & Students & \multicolumn{7}{|c|}{ completed up to five 1-minute trials per day. } \\
\hline & & \multicolumn{7}{|c|}{ R509 } \\
\hline & They & $\begin{array}{l}\text { set an } \\
\text { alarm } \\
\text { for } 1 \\
\text { minute, }\end{array}$ & (ellipsed) & \multicolumn{2}{|c|}{$\begin{array}{l}\text { read out the } \\
\text { phrase on the } \\
\text { front of each } \\
\text { card }\end{array}$} & And & (ellipsed) & $\begin{array}{l}\text { vocalised the } \\
\text { missing term } \\
\text { to complete } \\
\text { the statement. }\end{array}$ \\
\hline & Topical & & Topical & & & Textual & Topical & \\
\hline & T510 & R510 & T511 & & 511 & \multicolumn{2}{|c|}{ T512 } & R512 \\
\hline & They & \multicolumn{3}{|c|}{$\begin{array}{l}\text { then quickly checked the } \\
\text { back of each card to verify } \\
\text { whether their response was } \\
\text { correct or incorrect }\end{array}$} & And & (elllips & \multicolumn{2}{|c|}{$\begin{array}{l}\text { placed the card on } \\
\text { corresponding pile on } \\
\text { the table in from of } \\
\text { them }\end{array}$} \\
\hline & Topical & & & & Textual & Topi & & \\
\hline & T513 & \multicolumn{3}{|c|}{ R513 } & \multicolumn{2}{|c|}{ T514 } & \multicolumn{2}{|r|}{ R514 } \\
\hline $\begin{array}{l}\text { Constant } \\
\text { Theme } \\
\text { Pattern }\end{array}$ & $\begin{array}{l}\mathrm{T} 509- \\
\vdots \\
\mathrm{T} 510- \\
\vdots \\
\mathrm{T} 511 \\
\downarrow \\
\mathrm{T} 512- \\
\mathrm{T} 513 \\
\mathrm{~T} 514\end{array}$ & 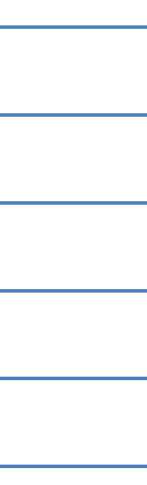 & $\begin{array}{l}\longrightarrow \mathrm{R} 509 \\
\longrightarrow \mathrm{R} 510 \\
\longrightarrow \mathrm{R} 511 \\
\longrightarrow \mathrm{R} 512 \\
\longrightarrow \mathrm{R} 513 \\
\mathrm{R} 514\end{array}$ & & & & & \\
\hline
\end{tabular}

\begin{tabular}{|c|c|c|c|c|}
\hline $\begin{array}{l}\text { Example } \\
\text { of Zig- } \\
\text { Zag }\end{array}$ & it & $\begin{array}{l}\text { can be conceptualised as occupying } \\
\text { the intracellular and extracellular } \\
\text { fluid compartments. }\end{array}$ & $\begin{array}{l}\text { Extracellular } \\
\text { fluid }\end{array}$ & $\begin{array}{l}\text { mainly comprises } \\
\text { plasma and interstitial } \\
\text { fluid, }\end{array}$ \\
\hline Theme & Topical & & Topical & \\
\hline Pattern & T11 & R11 & T12 & R12 \\
\hline
\end{tabular}

$\begin{array}{ll}\text { Zig-Zag } & \mathrm{T} 11 \quad \longrightarrow \mathrm{R} 11 \\ \text { Theme } & \mathrm{T} 12(\mathrm{R} 11) \longleftrightarrow \mathrm{R} 12 \\ \text { Pattern } & \longrightarrow\end{array}$

\begin{tabular}{|c|c|c|c|c|c|c|}
\hline \multirow[t]{3}{*}{$\begin{array}{l}\text { Example } \\
\text { of Split } \\
\text { Rheme } \\
\text { Pattern }\end{array}$} & $\begin{array}{l}\text { Some } \\
\text { incidents }\end{array}$ & $\begin{array}{l}\text { indicated } \\
\text { vulnerabilities } \\
\text { in systems: }\end{array}$ & One & $\begin{array}{l}\text { involved a } \\
\text { patient being } \\
\text { inaccurately } \\
\text { weighed without } \\
\text { any procedure } \\
\text { for double } \\
\text { checking; }\end{array}$ & $\begin{array}{l}\text { in } \\
\text { another, }\end{array}$ & $\begin{array}{l}\text { the existence of } \\
\text { two seemingly } \\
\text { discrepant } \\
\text { protocols made it } \\
\text { difficult to } \\
\text { identify unsafe } \\
\text { practice. }\end{array}$ \\
\hline & Topical & & Topical & & Topical & \\
\hline & T313 & R313 & T31 \{ & R3! \{ & T310 & R310 \\
\hline
\end{tabular}

$\begin{array}{ll}\text { Split } & \mathrm{T} 313 \longrightarrow \text { R313 } \\ \text { Rheme } & \mathrm{T} 314 \longleftrightarrow \text { R314 } \\ \text { Pattern } & \mathrm{T} 315 \longleftrightarrow \text { R315 }\end{array}$


Table 3. Thematic Progression Pattern Examples in Nonnative Texts

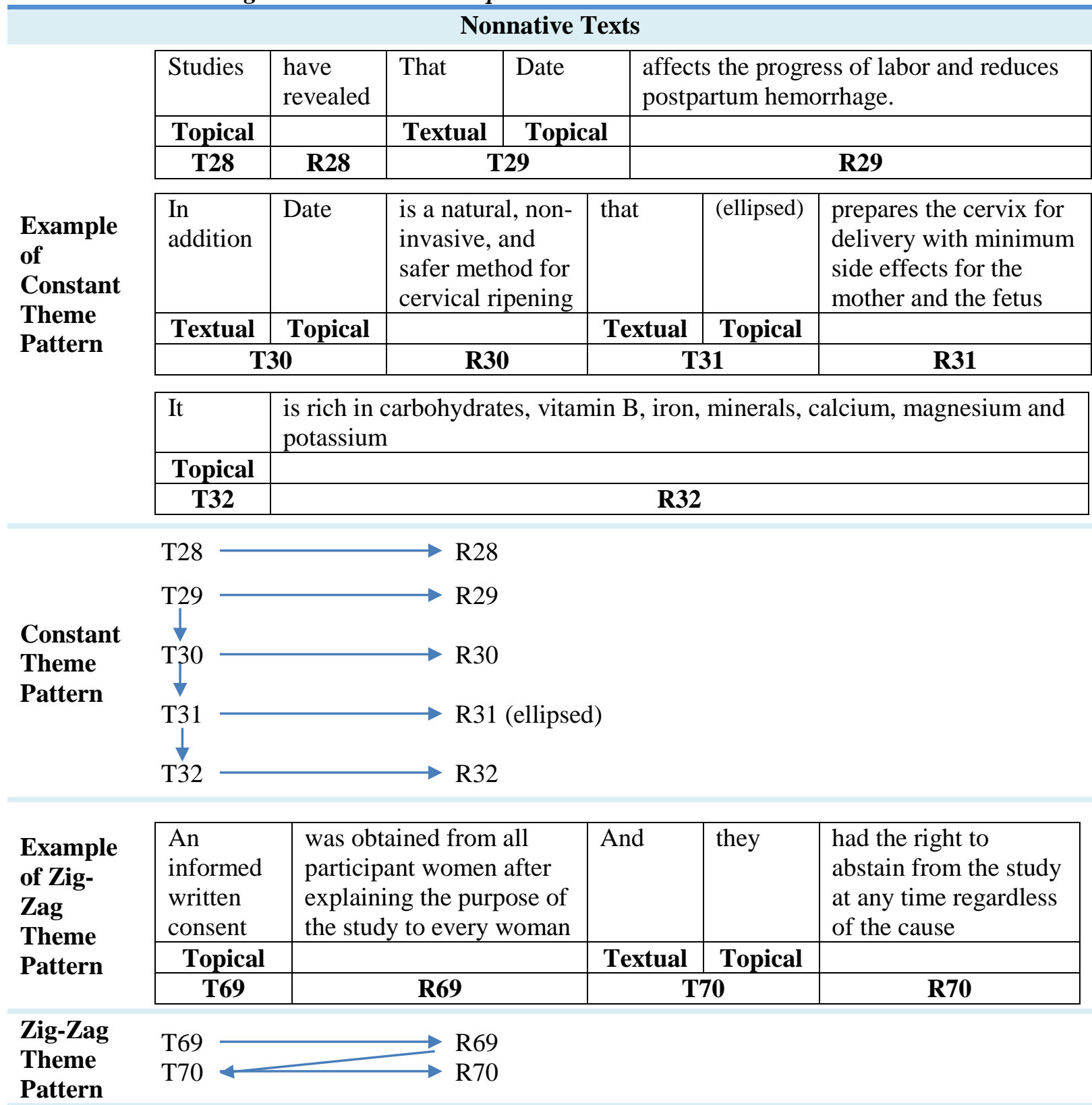

\begin{tabular}{|c|c|c|c|c|c|c|c|}
\hline \multirow[t]{3}{*}{$\begin{array}{l}\text { Example } \\
\text { of Split } \\
\text { Rheme } \\
\text { Pattern }\end{array}$} & $\begin{array}{l}\text { Fifty-four } \\
\text { primiparous } \\
\text { women }\end{array}$ & $\begin{array}{l}\text { were selected } \\
\text { randomly } \\
\text { according to } \\
\text { random number } \\
\text { generator on } \\
\text { every day and } \\
\text { divided equally } \\
\text { into study and } \\
\text { control groups. }\end{array}$ & $\begin{array}{l}\text { The } \\
\text { study } \\
\text { group }\end{array}$ & $\begin{array}{l}\text { received } \\
\text { water and } \\
\text { ate dates } \\
\text { ( } 7 \text { dates) } \\
\text { during the } \\
1^{\text {st }} \text { stage of } \\
\text { labor at } 6 \\
\mathrm{~cm} \\
\text { cervical } \\
\text { dilatation }\end{array}$ & And & $\begin{array}{l}\text { the } \\
\text { control } \\
\text { group }\end{array}$ & $\begin{array}{l}\text { receive } \\
\text { d IV } \\
\text { fluids as } \\
\text { routine } \\
\text { hospital } \\
\text { care } \\
\text { during } \\
\text { labor. }\end{array}$ \\
\hline & Topical & & Topical & & Textual & Topical & \\
\hline & T56 & R56 & T57 & R57 & \multicolumn{2}{|c|}{ T58 } & R58 \\
\hline $\begin{array}{l}\text { Split } \\
\text { Rheme } \\
\text { Pattern }\end{array}$ & \multicolumn{7}{|c|}{$\begin{array}{l}\mathrm{T} 56 \longrightarrow \mathrm{R} 56 \\
\mathrm{~T} 57 \longleftrightarrow \mathrm{R} 57 \\
\mathrm{~T} 58 \longleftrightarrow \mathrm{R} 58\end{array}$} \\
\hline
\end{tabular}

The constant Theme pattern (including ellipsed Theme patterns) comprised 55.3\% and $58.56 \%$ of the total occurrences of Theme patterns in native and nonnative texts respectively. 
The linear pattern was ranked second in both types of texts. Linear Theme patterns occurred with a percentage of $34.12 \%$ in native texts and $29.73 \%$ in nonnative texts. The use of the split Rheme patterns scored the lowest percentage among the other types of Thematic patterns in both texts. In native texts, the split Rheme patterns comprised $10.59 \%$ of the total number of Theme patterns, whereas it comprised $11.71 \%$ of nonnative texts. Table (4) shows the distribution of Thematic patterns in native and nonnative texts.

Table 4. Thematic Patterns in Native and Nonnative Texts

\begin{tabular}{|c|c|c|c|c|c|c|}
\hline Text type & Occurrences & $\begin{array}{l}\text { Constant } \\
\text { Theme } \\
\text { pattern }\end{array}$ & $\begin{array}{l}\text { Ellipsed } \\
\text { constant } \\
\text { Theme } \\
\text { pattern }\end{array}$ & $\begin{array}{l}\text { Linear } \\
\text { (zigzag) } \\
\text { Theme } \\
\text { pattern }\end{array}$ & $\begin{array}{l}\text { Split Rheme } \\
\text { (multiple } \\
\text { Theme) } \\
\text { pattern }\end{array}$ & $\begin{array}{l}\text { Total } \\
\text { number of } \\
\text { Thematic } \\
\text { patterns }\end{array}$ \\
\hline \multirow{2}{*}{$\begin{array}{l}\text { Nonnative } \\
\text { texts }\end{array}$} & Frequency & 26 & 39 & 33 & 13 & 111 \\
\hline & Percentage & $23.42 \%$ & $35.14 \%$ & $29.73 \%$ & $11.71 \%$ & $100 \%$ \\
\hline \multirow{2}{*}{$\begin{array}{l}\text { Native } \\
\text { texts }\end{array}$} & Frequency & 52 & 42 & 58 & 18 & 170 \\
\hline & Percentage & $30.59 \%$ & $24.71 \%$ & $34.12 \%$ & $10.59 \%$ & $100 \%$ \\
\hline
\end{tabular}

In relation to the distribution of Thematic progression types, the ranking of the three types is consistent with other studies (see Alyousef. 2015; Patpong, 2013; inter alia). The constant Theme pattern is the dominant type, followed by the linear pattern, and the least occurrences were those of the split Rheme pattern. However, it should be noted that there is a significant difference between the findings of the current study and the aforementioned studies with regard to the percentage of occurrence of each type. For example, the percentage of the constant Theme pattern in the study conducted by Alyousef (2015) was $94.76 \%$ whereas in this study it did not exceed $60 \%$ in native and nonnative texts.

\section{Problems with Thematic Selection and Progression}

The analysis of the Theme and Rheme in clauses aims to provide an indication of the flow of ideas which in turn leads to the cohesion of the text. Elements chosen to be placed in initial position attract the attention of readers to what needs to be emphasized in order to attain a valid interpretation of the intended meaning. When writers misuse the Theme and Rheme, problems occur and cause a difficulty to the readers of the text. Bloor and Bloor (1992) discussed the thematic organization of texts, basically in relation to Given and New information, and identified three problems that are common among writers and which result from misusing the Theme and Rheme. These problems include the problem of the brand new theme, the problem of the empty Rheme, and the problem of the double Rheme. The brand new theme problem occurs when writers place new information in the Theme position, which contradicts the normal position as the Theme is supposedly the carrier of Given information while the Rheme is the part that provides New information. This problem was found in the writings of nonnative medical researchers as shown in table (5). The authors of the article provided a subtitle "Tools: Two tools were developed and used by the researcher" and started describing them without any prior reference to the usage of tools or their purpose.

\section{Table 5. An Example of the Brand New Theme Problem in Nonnative Texts}

\begin{tabular}{ll}
\hline The first tool & includes three parts as the following: \\
Topical & Rheme R61 \\
\hline Theme T61 & Rhe
\end{tabular}

Similar to the problem of the brand new Theme, the misuse of the presentation of New and Given information can take place in the Rheme. This problem is referred to as the problem 
of the empty Rheme. It can be found in texts where writers fail to convey New information in the Rheme position. Table (6) provides an example of the empty Rheme problem in nonnative texts. The Rhemes in the following example did not provide any New information.

Table 6. An Example of the Empty Rheme Problem in Nonnative Texts

\begin{tabular}{lllll}
\hline $\begin{array}{l}\text { The variables } \\
\text { Topical }\end{array}$ & were coded & $\begin{array}{l}\text { And } \\
\text { Textual }\end{array}$ & $\begin{array}{l}\text { data entry } \\
\text { Topical }\end{array}$ & carried out \\
\hline Theme T109 & Rheme R109 & Theme T110 & Rheme R110 \\
\hline
\end{tabular}

The problem of the double Rheme happens when the clause contains a second Rheme that refers to an entity that was not previously mentioned in the text. Table (7) includes an example of this problem in nonnative texts. In the last Rheme (R29), the writers included a second Rheme about postpartum hemorrhage that was not previously mentioned.

\section{Table 7. An Example of the Double Rheme Problem in Nonnative Texts}

\begin{tabular}{lllll}
\hline Studies & have revealed & That & date & $\begin{array}{l}\text { affects the progress of labor and } \\
\text { reduces postpartum hemorrhage. }\end{array}$ \\
Topical & & Textual & Topical & \\
Theme T28 & Rheme R28 & Theme T29 & & Rheme R29 \\
\hline
\end{tabular}

The overuse of the constant Theme pattern, as described by McCabe-Hidalgo and Belmonte (1998), is a well-known problem that relates to Thematic progression. This is a prevalent problem found in many studies that investigate Thematic progression patterns such as those of Kuswoyo and Susardi (2017) and Arunsirot (2013). However, this problem was not found in the analyzed texts. This can be attributed to the frequency of the occurrences of constant Theme patterns in the present study which is significantly lower than other studies.

A major problem that was found in the analyzed texts was the lack of Thematic progression. This is characterized by a lack of interconnectedness of ideas in the texts. The presentation of ideas in major portions of the texts lacked coherence. The articles tended to focus on stating scientific facts without attempting to connect the ideas together. Table (8) shows an example of sentences that lack Thematic progression patterns.

\section{Table 8. An Excerpt of Nonnative Texts With No Thematic Progression}

Tools of the study were developed by the researcher after reviewing the literatures.

\section{Topical}

Theme T72

The tool content validity

\section{Rheme R72}

was tested by five juries who are experts in the related field

\section{Topical}

Theme T73

\section{Rheme R73}

Content

And validity index was considered.

(CVI)

Textual Topical

Theme T74

\section{Rheme R74}

Cronbach's Alpha was applied to assess the reliability of the tools. $0.85 \& 0.83$ for tools I $\&$ II respectively.

Topical

Theme T75

Rheme R75 


\begin{tabular}{ll}
\hline A pilot study & was carried out on $10 \%$ (5 women) of the sample. \\
Topical & \\
\hline Theme T76 & Rheme R76 \\
\hline
\end{tabular}

Clearly, and as shown in table (8) above, the sentences in this excerpt lack Thematic progression. The writers listed the facts in a paragraph that seemed more like a list than a cohesive entity. There was no Thematic progression at all in the previous example as shown in the analysis below:

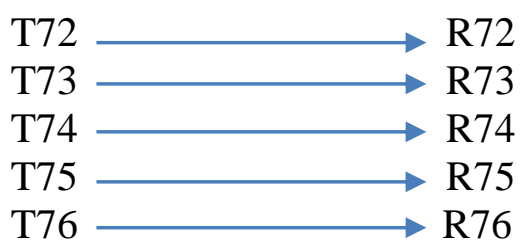

Other problems that were also discussed by Belmonte and McCabe-Hidalgo (1998) include the problems of the overuse of the indefinite it as well as there in the Theme selection. These problems were observed in the native and nonnative texts alike. Writers sometimes used a dummy it to begin sentences without a clear reference. It was also observed that they tended to rely on the use of there as it is a simple strategy to begin sentences. Tables (9) and (10) show examples from both types of texts.

Table 9. Examples of the Overuse of the Indefinite it

\begin{tabular}{|c|c|c|}
\hline \multirow{3}{*}{ Native texts } & It & $\begin{array}{l}\text { is possible to lose } 1-2 \mathrm{~L} \text { of fluid per day from a high output } \\
\text { stoma, }\end{array}$ \\
\hline & Topical & \\
\hline & Theme T135 & Rheme R135 \\
\hline \multirow[t]{3}{*}{$\begin{array}{l}\text { Nonnative } \\
\text { texts }\end{array}$} & It & $\begin{array}{l}\text { seems that there was a relationship between the decline in core } \\
\text { temperature and reducing shivering so that core temperature in } \\
\text { the intervention group was more stable while it declined in the } \\
\text { control group. }\end{array}$ \\
\hline & Topical & \\
\hline & Theme T507 & Rheme R507 \\
\hline
\end{tabular}

Table 10. Examples of the Overuse of There

\begin{tabular}{lll}
\hline \multirow{2}{*}{ Native texts } & $\begin{array}{l}\text { There } \\
\text { Topical }\end{array}$ & $\begin{array}{l}\text { is a lack of high quality evidence, such as that from randomised } \\
\text { controlled trials, to guide intravenous fluid management. }\end{array}$ \\
& $\begin{array}{l}\text { Theme T7 } \\
\text { Nonnative }\end{array}$ & $\begin{array}{l}\text { There } \\
\text { Reme } \mathbf{R 7}\end{array}$ \\
\hline texts & Topical & \\
\cline { 2 - 3 } & Theme $\mathbf{T 5 2 5}$ & Rheme change in the amount of SpO2, \\
\hline
\end{tabular}

Lastly, a problem that the researcher observed while analyzing the thematic selection and progression of the examined nonnative texts related to the use of reference. It was noticed that the authors sometimes used reference to an entity that was mentioned much earlier. This gap created by the intervening clauses between the reference and its entity caused the text to be incoherent and obscure to readers. Table (11) provides an example to illustrate this point. The writers used "this" in the $17^{\text {th }}$ clause to refer to a study by Mendelson that was mentioned earlier in the $11^{\text {th }}$ clause. 


\section{Table 11. Example of a Gap between a Reference and its Entity}

As a consequence of this early research

Topical

Theme T17 it is always assumed that the laboring mother has a full stomach

\section{CONCLUSION AND IMPLICATIONS}

The organization of texts is the core of successful communication. This fundamentally highlights the importance of paying close attention to what needs to be allocated as a Theme and how it progresses in the text. The present study examined medical articles written by native and nonnative researchers in relation to their use of the Theme and Rheme, as well as the Thematic progression of their articles. This aimed to inspect whether there are differences or similarities between medical articles written by native and nonnative writers, and whether medical texts in general are in alignment with the findings of studies in other fields such as academia.

Despite being produced by two different groups, native and nonnative writers, analyzing medical texts yielded similar results. Of Theme types, the most frequently used Theme type was the topical Theme, followed by the textual Theme, and finally by the interpersonal Theme that was barely used, which is normally the case with scientific writings that aspire to project objectivity. Similarly, the analysis of Thematic progression patterns in both native and nonnative texts indicated the dominance of the constant Theme pattern over the other types. The linear pattern was ranked in second place, and the lowest frequency recorded was that of the occurrence of the split Rheme pattern. It was observed that the findings of the analysis of Theme and Thematic progression in medical texts was consistent with the results found in studies of other fields. While other studies focused on the analysis of texts of a certain type, the present study differs in two ways. Firstly, it provides insights about the performance of native and nonnative writers within the same text type; which is the medical field. Secondly, it verifies the existence of problems that relate to theme selection and progression in the writings of medical articles, which are found in other fields of study. Future work can inspect the similarities and differences between native and nonnative writings of medical academic writing such as books, MA theses, and P.hD. dissertations.

\section{REFERENCES}

Abdul Ridha, N. S. (2014). Theme and Rheme: Types and Problems in EFL University Students' Written Texts. Journal of Basra researches for Human Sciences, 39(1), 93-114.

Al-Ohali, M., \& Shin, J. C. (2013). Knowledge-based innovation and research productivity in Saudi Arabia. In Higher Education in Saudi Arabia (pp. 95-102): Springer.

Alyousef, H. S. (2015). A multimodal discourse analysis of international postgraduate business students' finance texts: an investigation of theme and information value. Social Semiotics, 26(5), 486-504. doi:10.1080/10350330.2015.1124518

Arunsirot, S. (2013). An Analysis of Textual Metafunction in Thai EFL Students' Writing. Novitas-ROYAL (Research on Youth and Language), 7(2), 160-174.

Atkinson, D., \& Ellen V. (2012). Corpus analysis of scientific and medical writing across time. In Chapelle, Carol A. (ed.), The Encyclopedia of Applied Linguistics. Malden: Blackwell, 1347-1353. doi: 10.1002/9781405198431.wbeal0251 
Bloor, M., and T. Bloor, (1992). Given and new information in the thematic organization of text: An application to the teaching of academic writing. Occasional Papers in Systemic Linguistics, Vol 6,pp: 33-44.

Daneš, F. (1974). Functional sentence perspective and the organization of the text. Papers on functional sentence perspective, 106-128.

Eggins, S. (2004). Introduction to systemic functional linguistics: A\&C Black.

Gotti, M., \& Salager-Meyer, F. (2006). Advances in medical discourse analysis: Oral and written contexts (Vol. 45): Peter Lang. doi: 10.3726/978-3-0351-0396-0

Gunawan, W., \& Aziza, F. (2017). Theme and thematic progression of undergraduate thesis: Investigating meaning making in academic writing. Indonesian Journal of Applied Linguistics, 7(2), 413-424. doi:10.17509/ijal.v7i2.8350

Halliday, M. A. K., \& Hasan, R. (1976). Cohesion in English. London: Longman.

Halliday, M. A. K., \& Matthiessen, C. (2004). An Introduction to Functional Grammar (3rd ed.) London: Hodder education.

Halliday, M., \& Webster, J. (2004). The Language of Science (5th ed.). London, United Kingdom: Bloomsbury Publishing PLC.

Kazemi, F. (2015). Theme markedness in Persian and English medical texts: a systemicfunctional approach. Theory and Practice in Language Studies, 5(11), 2416-2425. doi: $\underline{10.17507 / t p / s .0511 .29}$

Kuswoyo, H., \& Susardi, S. (2017). Problems on SFG thematic progression in ESL academic writing. LEKSEMA: Jurnal Bahasa dan Sastra, 2(1), 1-13. doi:10.22515/libs.v2i1.655

McCabe-Hidalgo, A., \& Belmonte, I. (1998). Theme-rheme patterns in L2 writing. Didáctica: Lengua y Literatura, 10, 13.

Noori, B. F. (2015). An Analysis of Textual Themes in MA Theses and Ph. D. Dissertations. Journal of the College of Languages (32), 48-59.

Patpong, P. (2013). Thematic Progression of Thai Song Dam Folktales. Journal of the Southeast Asian Linguistics Society (JSEALS), 9, 189-215.

Rodríguez-Vergara, D. (2017). A systemic functional approach to the passive voice in English into Spanish translation: Thematic development in a medical research article. Open Linguistics, 3(1), 1-17. doi:10.1515/opli-2017-0001

Salager-Meyer, F. (1994). Hedges and textual communicative function in medical English written discourse. English for Specific Purposes, 13(2), 149-171. doi: 10.1016/0889-4906(94)90013$\underline{2}$

Wang, L. (2007). Theme and rheme in the thematic organization of text: Implications for teaching academic writing. Asian EFL Journal, 9(1), 164-176. 
APPENDIX (A)

Theme Frequencies - Nonnative texts

Article 1

\begin{tabular}{|l|c|l|c|l|l|}
\hline & $\begin{array}{l}\text { Topical } \\
\text { Theme }\end{array}$ & $\begin{array}{l}\text { Ellipsed } \\
\text { Topical } \\
\text { Theme }\end{array}$ & Textual Theme & $\begin{array}{l}\text { Interpersonal } \\
\text { Theme }\end{array}$ & $\begin{array}{l}\text { Total } \\
\text { number of } \\
\text { Themes }\end{array}$ \\
\hline Frequency & 158 & 21 & 80 & 3 & 262 \\
\hline Percentage & $60.31 \%$ & $8.02 \%$ & $30.53 \%$ & $1.15 \%$ & $100 \%$ \\
\hline
\end{tabular}

Article 2

\begin{tabular}{|l|c|l|c|l|l|}
\hline & $\begin{array}{l}\text { Topical } \\
\text { Theme }\end{array}$ & $\begin{array}{l}\text { Ellipsed } \\
\text { Topical } \\
\text { Theme }\end{array}$ & Textual Theme & $\begin{array}{l}\text { Interpersonal } \\
\text { Theme }\end{array}$ & $\begin{array}{l}\text { Total } \\
\text { number of } \\
\text { Themes }\end{array}$ \\
\hline Frequency & 107 & 13 & 52 & 0 & 172 \\
\hline Percentage & $62.21 \%$ & $7.56 \%$ & $30.23 \%$ & $0.00 \%$ & $100 \%$ \\
\hline
\end{tabular}

Article 3

\begin{tabular}{|l|c|l|c|l|c|}
\hline & $\begin{array}{l}\text { Topical } \\
\text { Theme }\end{array}$ & $\begin{array}{l}\text { Ellipsed } \\
\text { Topical } \\
\text { Theme }\end{array}$ & Textual Theme & $\begin{array}{l}\text { Interpersonal } \\
\text { Theme }\end{array}$ & $\begin{array}{l}\text { Total } \\
\text { number of } \\
\text { Themes }\end{array}$ \\
\hline Frequency & 214 & 22 & 124 & 1 & 361 \\
\hline Percentage & $59.28 \%$ & $6.09 \%$ & $34.35 \%$ & $0.28 \%$ & $100 \%$ \\
\hline
\end{tabular}

Total statistics

\begin{tabular}{|l|c|l|c|l|l|}
\hline & $\begin{array}{l}\text { Topical } \\
\text { Theme }\end{array}$ & $\begin{array}{l}\text { Ellipsed } \\
\text { Topical } \\
\text { Theme }\end{array}$ & Textual Theme & $\begin{array}{l}\text { Interpersonal } \\
\text { Theme }\end{array}$ & $\begin{array}{l}\text { Total } \\
\text { number of } \\
\text { Themes }\end{array}$ \\
\hline Frequency & 479 & 56 & 256 & 4 & 795 \\
\hline Percentage & $60.25 \%$ & $7.04 \%$ & $32.20 \%$ & $0.50 \%$ & $100 \%$ \\
\hline
\end{tabular}

APPENDIX (B)

Theme Frequencies - Native texts

Article 1

\begin{tabular}{|l|l|l|c|l|l|}
\hline & $\begin{array}{l}\text { Topical } \\
\text { Theme }\end{array}$ & $\begin{array}{l}\text { Ellipsed } \\
\text { Topical } \\
\text { Theme }\end{array}$ & Textual Theme & $\begin{array}{l}\text { Interpersonal } \\
\text { Theme }\end{array}$ & $\begin{array}{l}\text { Total } \\
\text { number of } \\
\text { Themes }\end{array}$ \\
\hline Frequency & 126 & 15 & 66 & 4 & 211 \\
\hline Percentage & $59.72 \%$ & $7.11 \%$ & $31.28 \%$ & $1.9 \%$ & $100 \%$ \\
\hline
\end{tabular}

Article 2 


\begin{tabular}{|l|c|l|c|l|l|}
\hline & $\begin{array}{l}\text { Topical } \\
\text { Theme }\end{array}$ & $\begin{array}{l}\text { Ellipsed } \\
\text { Topical } \\
\text { Theme }\end{array}$ & Textual Theme & $\begin{array}{l}\text { Interpersonal } \\
\text { Theme }\end{array}$ & $\begin{array}{l}\text { Total } \\
\text { number of } \\
\text { Themes }\end{array}$ \\
\hline Frequency & 232 & 37 & 107 & 6 & 382 \\
\hline Percentage & $60.73 \%$ & $9.69 \%$ & $28.01 \%$ & $1.57 \%$ & $100 \%$ \\
\hline
\end{tabular}

Article 3

\begin{tabular}{|l|c|l|c|l|l|}
\hline & $\begin{array}{l}\text { Topical } \\
\text { Theme }\end{array}$ & $\begin{array}{l}\text { Ellipsed } \\
\text { Topical } \\
\text { Theme }\end{array}$ & Textual Theme & $\begin{array}{l}\text { Interpersonal } \\
\text { Theme }\end{array}$ & $\begin{array}{l}\text { Total } \\
\text { number of } \\
\text { Themes }\end{array}$ \\
\hline Frequency & 154 & 36 & 88 & 4 & 282 \\
\hline Percentage & $54.61 \%$ & $12.77 \%$ & $31.21 \%$ & $1.42 \%$ & $100 \%$ \\
\hline
\end{tabular}

Article 4

\begin{tabular}{|l|c|l|c|l|l|}
\hline & $\begin{array}{l}\text { Topical } \\
\text { Theme }\end{array}$ & $\begin{array}{l}\text { Ellipsed } \\
\text { Topical } \\
\text { Theme }\end{array}$ & Textual Theme & $\begin{array}{l}\text { Interpersonal } \\
\text { Theme }\end{array}$ & $\begin{array}{l}\text { Total } \\
\text { number of } \\
\text { Themes }\end{array}$ \\
\hline Frequency & 151 & 63 & 100 & 6 & 320 \\
\hline Percentage & $47.19 \%$ & $19.69 \%$ & $31.25 \%$ & $1.88 \%$ & $100 \%$ \\
\hline
\end{tabular}

Total statistics

\begin{tabular}{|l|c|l|c|l|l|}
\hline & $\begin{array}{l}\text { Topical } \\
\text { Theme }\end{array}$ & $\begin{array}{l}\text { Ellipsed } \\
\text { Topical } \\
\text { Theme }\end{array}$ & Textual Theme & $\begin{array}{l}\text { Interpersonal } \\
\text { Theme }\end{array}$ & $\begin{array}{l}\text { Total } \\
\text { number of } \\
\text { Themes }\end{array}$ \\
\hline Frequency & 663 & 151 & 361 & 20 & 1195 \\
\hline Percentage & $55.48 \%$ & $12.64 \%$ & $30.21 \%$ & $1.67 \%$ & $100 \%$ \\
\hline
\end{tabular}

\section{APPENDIX (C)}

Thematic Progression Frequencies - Nonnative texts

Article 1

\begin{tabular}{|l|l|l|c|l|c|}
\hline & $\begin{array}{l}\text { Constant } \\
\text { Theme } \\
\text { pattern }\end{array}$ & $\begin{array}{l}\text { Ellipsed } \\
\text { constant } \\
\text { Theme } \\
\text { pattern }\end{array}$ & $\begin{array}{l}\text { Linear (zigzag) } \\
\text { Theme pattern }\end{array}$ & $\begin{array}{l}\text { Split Rheme } \\
\text { (multiple } \\
\text { Theme) } \\
\text { pattern }\end{array}$ & $\begin{array}{l}\text { Total number } \\
\text { of Thematic } \\
\text { patterns }\end{array}$ \\
\hline Frequency & 9 & 13 & 13 & 5 & 40 \\
\hline Percentage & $22.5 \%$ & $32.5 \%$ & $32.5 \%$ & $12.5 \%$ & $100 \%$ \\
\hline
\end{tabular}

Article 2

\begin{tabular}{|l|l|l|c|l|c|}
\hline & $\begin{array}{l}\text { Constant } \\
\text { Theme } \\
\text { pattern }\end{array}$ & $\begin{array}{l}\text { Ellipsed } \\
\text { constant } \\
\text { Theme } \\
\text { pattern }\end{array}$ & $\begin{array}{l}\text { Linear (zigzag) } \\
\text { Theme pattern }\end{array}$ & $\begin{array}{l}\text { Split Rheme } \\
\text { (multiple } \\
\text { Theme) } \\
\text { pattern }\end{array}$ & $\begin{array}{l}\text { Total number } \\
\text { of Thematic } \\
\text { patterns }\end{array}$ \\
\hline Frequency & 4 & 10 & 11 & 4 & 29 \\
\hline Percentage & $13.79 \%$ & $34.48 \%$ & $37.93 \%$ & $13.79 \%$ & $100 \%$ \\
\hline
\end{tabular}


Article 3

\begin{tabular}{|l|c|l|c|l|c|}
\hline & $\begin{array}{l}\text { Constant } \\
\text { Theme } \\
\text { pattern }\end{array}$ & $\begin{array}{l}\text { Ellipsed } \\
\text { constant } \\
\text { Theme } \\
\text { pattern }\end{array}$ & $\begin{array}{l}\text { Linear (zigzag) } \\
\text { Theme pattern }\end{array}$ & $\begin{array}{l}\text { Split Rheme } \\
\text { (multiple } \\
\text { Theme) } \\
\text { pattern }\end{array}$ & $\begin{array}{l}\text { Total number } \\
\text { of Thematic } \\
\text { patterns }\end{array}$ \\
\hline Frequency & 13 & 16 & 9 & 4 & 42 \\
\hline Percentage & $30.95 \%$ & $38.1 \%$ & $21.43 \%$ & $9.52 \%$ & $100 \%$ \\
\hline
\end{tabular}

Total statistics

\begin{tabular}{|l|c|l|c|l|c|}
\hline & $\begin{array}{l}\text { Constant } \\
\text { Theme } \\
\text { pattern }\end{array}$ & $\begin{array}{l}\text { Ellipsed } \\
\text { constant } \\
\text { Theme } \\
\text { pattern }\end{array}$ & $\begin{array}{l}\text { Linear (zigzag) } \\
\text { Theme pattern }\end{array}$ & $\begin{array}{l}\text { Split Rheme } \\
\text { (multiple } \\
\text { Theme) } \\
\text { pattern }\end{array}$ & $\begin{array}{l}\text { Total number } \\
\text { of Thematic } \\
\text { patterns }\end{array}$ \\
\hline Frequency & 26 & 39 & 33 & 13 & 111 \\
\hline Percentage & $23.42 \%$ & $35.14 \%$ & $29.73 \%$ & $11.71 \%$ & $100 \%$ \\
\hline
\end{tabular}

APPENDIX (D)

Thematic Progression Frequencies - Native texts

Article 1

\begin{tabular}{|l|l|l|c|l|c|}
\hline & $\begin{array}{l}\text { Constant } \\
\text { Theme } \\
\text { pattern }\end{array}$ & $\begin{array}{l}\text { Ellipsed } \\
\text { constant } \\
\text { Theme } \\
\text { pattern }\end{array}$ & $\begin{array}{l}\text { Linear (zigzag) } \\
\text { Theme pattern }\end{array}$ & $\begin{array}{l}\text { Split Rheme } \\
\text { (multiple } \\
\text { Theme) } \\
\text { pattern }\end{array}$ & $\begin{array}{l}\text { Total number } \\
\text { of Thematic } \\
\text { patterns }\end{array}$ \\
\hline Frequency & 8 & 4 & 16 & 4 & 32 \\
\hline Percentage & $25 \%$ & $12.5 \%$ & $50 \%$ & $12.5 \%$ & $100 \%$ \\
\hline
\end{tabular}

Article 2

\begin{tabular}{|l|l|l|c|l|c|}
\hline & $\begin{array}{l}\text { Constant } \\
\text { Theme } \\
\text { pattern }\end{array}$ & $\begin{array}{l}\text { Ellipsed } \\
\text { constant } \\
\text { Theme } \\
\text { pattern }\end{array}$ & $\begin{array}{l}\text { Linear (zigzag) } \\
\text { Theme pattern }\end{array}$ & $\begin{array}{l}\text { Split Rheme } \\
\text { (multiple } \\
\text { Theme) } \\
\text { pattern }\end{array}$ & $\begin{array}{l}\text { Total number } \\
\text { of Thematic } \\
\text { patterns }\end{array}$ \\
\hline Frequency & 16 & 15 & 17 & 6 & 54 \\
\hline Percentage & $29.63 \%$ & $27.78 \%$ & $31.48 \%$ & $11.11 \%$ & $100 \%$ \\
\hline
\end{tabular}

Article 3

\begin{tabular}{|l|l|l|c|l|c|}
\hline & $\begin{array}{l}\text { Constant } \\
\text { Theme } \\
\text { pattern }\end{array}$ & $\begin{array}{l}\text { Ellipsed } \\
\text { constant } \\
\text { Theme } \\
\text { pattern }\end{array}$ & $\begin{array}{l}\text { Linear (zigzag) } \\
\text { Theme pattern }\end{array}$ & $\begin{array}{l}\text { Split Rheme } \\
\text { (multiple } \\
\text { Theme) } \\
\text { pattern }\end{array}$ & $\begin{array}{l}\text { Total number } \\
\text { of Thematic } \\
\text { patterns }\end{array}$ \\
\hline Frequency & 16 & 7 & 15 & 3 & 41 \\
\hline Percentage & $39.02 \%$ & $17.07 \%$ & $36.59 \%$ & $7.32 \%$ & $100 \%$ \\
\hline
\end{tabular}


Article 4

\begin{tabular}{|l|l|l|c|l|l|}
\hline & $\begin{array}{l}\text { Constant } \\
\text { Theme } \\
\text { pattern }\end{array}$ & $\begin{array}{l}\text { Ellipsed } \\
\text { constant } \\
\text { Theme } \\
\text { pattern }\end{array}$ & $\begin{array}{l}\text { Linear (zigzag) } \\
\text { Theme pattern }\end{array}$ & $\begin{array}{l}\text { Split Rheme } \\
\text { (multiple } \\
\text { Theme) } \\
\text { pattern }\end{array}$ & $\begin{array}{l}\text { Total number } \\
\text { of Thematic } \\
\text { patterns }\end{array}$ \\
\hline Frequency & 12 & 16 & 10 & 5 & 43 \\
\hline Percentage & $27.91 \%$ & $37.21 \%$ & $23.26 \%$ & $11.63 \%$ & $100 \%$ \\
\hline
\end{tabular}

Total statistics

\begin{tabular}{|l|l|l|c|l|c|}
\hline & $\begin{array}{l}\text { Constant } \\
\text { Theme } \\
\text { pattern }\end{array}$ & $\begin{array}{l}\text { Ellipsed } \\
\text { constant } \\
\text { Theme } \\
\text { pattern }\end{array}$ & $\begin{array}{l}\text { Linear (zigzag) } \\
\text { Theme pattern }\end{array}$ & $\begin{array}{l}\text { Split Rheme } \\
\text { (multiple } \\
\text { Theme) } \\
\text { pattern }\end{array}$ & $\begin{array}{l}\text { Total number } \\
\text { of Thematic } \\
\text { patterns }\end{array}$ \\
\hline Frequency & 52 & 42 & 58 & 18 & 170 \\
\hline Percentage & $30.59 \%$ & $24.71 \%$ & $34.12 \%$ & $10.59 \%$ & $100 \%$ \\
\hline
\end{tabular}

\section{AUTHOR'S BIO}

Mashael Alrajhi is a lecturer at the Department of Applied Linguistics, College of Languages, Princess Nourah bint Abdulrahman University. She holds a BA in English language and literature, an MA in linguistics, and is currently a PhD candidate at King Saud University. Her areas of interest are phonetics \& phonology, sociolinguistics, forensic linguistics, and CALL. 